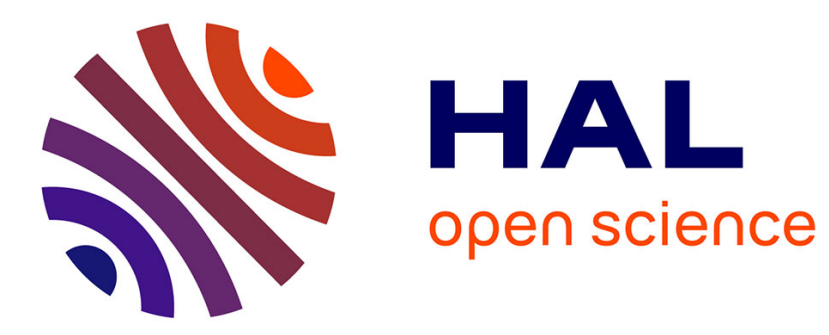

\title{
Should we control the pineal status of patients following brain radiotherapy?
}

Nelly Wion-Barbot, François R. Berger, Didier Wion

\section{To cite this version:}

Nelly Wion-Barbot, François R. Berger, Didier Wion. Should we control the pineal status of patients following brain radiotherapy?. Journal of Neuro-Oncology, 2005, 74 (3), pp.335. 10.1007/s11060-0050829-4 . inserm-00391126

\section{HAL Id: inserm-00391126 https://www.hal.inserm.fr/inserm-00391126}

Submitted on 31 Jul 2009

HAL is a multi-disciplinary open access archive for the deposit and dissemination of scientific research documents, whether they are published or not. The documents may come from teaching and research institutions in France or abroad, or from public or private research centers.
L'archive ouverte pluridisciplinaire HAL, est destinée au dépôt et à la diffusion de documents scientifiques de niveau recherche, publiés ou non, émanant des établissements d'enseignement et de recherche français ou étrangers, des laboratoires publics ou privés. 
Nelly Wion-Barbot, François Berger ${ }^{\#}$ and Didier Wion * .

Service Endocrinologie Diabétologie Nutrition, CHU Grenoble, Université J. Fourier, 38043 Grenoble Cedex France ; INSERM U318, CHU Michallon 38043 Grenoble Cedex France.

* corresponding author : didier.wion@ujf-grenoble.fr 
In addition to cognitive deficits and dementia, endocrine disturbances are one of the major late adverse effect of brain radiotherapy (1). Thus, hypothalamic-pituitary hormone deficiencies following cranial irradiation have been extensively studied, and a high frequency of growth hormone deficiency has been reported (2). However, the incidence and severity of pineal deficiency after cranial irradiation have retained little attention. In human, the pineal gland lies in the center of the brain, behind the third ventricule. This neuroendocrine gland produces both peptides (such as arginin vasotocin) and indolamines (such as melatonin) (3). Regarding the possible function of melatonin in brain physiology, it must be pointed out that this pineal hormone has recently been shown to exert neuroprotective activity in a variety of experimental neuropathologies in which free radicals are involved $(4,5)$. Hence, reductions in melatonin could increase the consequences of the late adverse effects of radiotherapy on cognitive and neuropsychological disturbances. Moreover, pineal gland can be involved in the regulation of tumour growth through the anticancer activity of melatonin (6), a point of peculiar concern if we consider the use of radiation therapy in the management of patients with brain metastases. In this regard, it is noteworthy that inhibition of the pineal function may stimulate mammary carcinogenesis (7). Taken together, these points raise the importance of evaluating the pineal status of patients after brain radiotherapy when the pineal gland falls within the fields of irradiation. Careful monitoring of plasma or cerebrospinal fluid melatonin could be used as a marker of the changes in the pineal functions, and should lead to the inclusion of pineal hormones in the optimal management of hormone deficiencies consecutive to brain radiotherapy. 


\section{References:}

1. Johannesen TB, Lien HH, Hole KH, Lote K: Radiological and clinical assessment of long-term brain tumour survivors after radiotherapy. Radiother Oncol. 69:169-76, 2003.

2. Adan C, Sainte-Rose J, Zucker M, Hartmann O, Brauner R: GH deficiency caused by cranial irradiation during childhood: Factors and markers in young adults. J Clin Endocrinol Metab 86: 5245-51, 2001.

3. Brzezinski A: Melatonin in humans. N Engl J Med. 336:186-95, 1997.

4. Kostrzewa RM, Segura-Aguilar J: Novel mechanisms and approaches in the study of neurodegeneration and neuroprotection. A review. Neurotox. Res. 5: 375$383,2003$.

5. Lee EJ, Lee MY, Cen HY, Hsu YS, Wu TS, Chen ST, Chan GL: Melatonin attenuates gray and white matter damage in a mouse model of transient focal cerebral ischemia. J. Pineal Res. 38: 42-52, 2005.

6. Reiter J. Mechanisms of cancer inhibition by melatonin: J. Pinel Res. 37: 213-214, 2004.

7. Anisimov V: The role of pineal gland in breast cancer development. Crit Rev Oncol Hematol. 46: 221-34, 2003. 